\title{
Effect of Different Surface Penetrating Sealants on the Roughness of a Nanofiller Composite Resin
}

\author{
Murilo Baena LOPES ${ }^{1}$ \\ Paulo Cesar SAQUY ${ }^{1}$ \\ Sandra Kiss MOURA ${ }^{1}$ \\ Linda $\mathrm{WANG}^{2}$ \\ Fabiana Mezzaroba Ortenzi GRACIANO ${ }^{1}$ \\ Lourenço CORRER SOBRINHO 3 \\ Alcides GONINI JÚNIOR ${ }^{1}$ \\ ${ }^{1}$ Department of Dentistry, Dental School, UNOPAR - University of North Parana, Londrina, PR, Brazil \\ ${ }^{2}$ Department of Endodontics, Restorative Dentistry and Dental Materials, \\ Bauru Dental School, USP - University of São Paulo, Bauru, SP, Brazil \\ ${ }^{3}$ Department of Restorative Dentistry, Piracicaba Dental School, \\ UNICAMP - University of Campinas, Piracicaba, SP, Brazil
}

\begin{abstract}
This study evaluated the effectiveness of different sealants applied to a nanofiller composite resin. Forty specimens of Filtek Z-350 were obtained after inserting the material in a $6 \times 3 \mathrm{~mm}$ stainless steel mold followed by light activation for $20 \mathrm{~s}$. The groups were divided $(\mathrm{n}=10)$ according to the surface treatment applied: Control group (no surface treatment), Fortify, Fortify Plus and Biscover LV. The specimens were subjected to simulated toothbrushing using a $200 \mathrm{~g}$ load and 250 strokes/min to simulate 1 week, 1, 3 and 6 months and 1 and 3 years in the mouth, considering 10,000 cycles equivalent to 1 year of toothbrushing. Oral-B soft-bristle-tip toothbrush heads and Colgate Total dentifrice at a 1:2 water-dilution were used. After each simulated time, surface roughness was assessed in random triplicate readings. The data were submitted to two-way ANOVA and Tukey's test at a 95\% confidence level. The specimens were observed under scanning electron microscopy (SEM) after each toothbrushing cycle. The control group was not significantly different $(p>0.05)$ from the other groups, except for Fortify Plus $(p<0.05)$, which was rougher. No significant differences $(p>0.05)$ were observed at the 1-month assessment between the experimental and control groups. Fortify and Fortify Plus presented a rougher surface over time, differing from the baseline $(\mathrm{p}<0.05)$. Biscover LV did not differ $(\mathrm{p}>0.05)$ from the baseline at any time. None of the experimental groups showed a significantly better performance $(\mathrm{p}>0.05)$ than the control group at any time. SEM confirmed the differences found during the roughness testing. Surface penetrating sealants did not improve the roughness of nanofiller composite resin.
\end{abstract}

Key Words: surface sealant, toothbrushing, roughness, SEM.

\section{INTRODUCTION}

Since the introduction of bonding systems and composite resins, wear and microleakage were the primary clinical limitations, mainly in posterior restorations (1-8). The relative porosity of the restorative and absorption/adsorption of oral fluids may also allow staining agents to penetrate the material (9). In order to improve wear resistance, some specific composites were formulated $(7,10)$. A more recent evolution of composite resins is associated with nanotechnology, resulting in materials that have better mechanical strength and high-polishing durability. These new materials are for universal use, according to the manufacturers (11).

Surface-penetrating sealants were developed to avoid or minimize wear rates of composite resins by filling the microdefects on the restoration surface and to reduce microleakage along the restoration/ tooth interface (4-6,12). Additionally, some sealants also act as a chemical gloss by reducing the surface roughness (13). Different formulations of these materials are currently available on the market in a range of combined monomers, such as BisGMA (bisphenolA-glycidyl dimethacrylate), TEGDMA (triethylene 
glycol dimethacrylate), THFMA (tetrahydrofurfuryl methacrylate) and UDMA (urethane dimethacrylate) (14). Fillers were added to some materials to increase their mechanical properties $(4,6,12,13)$.

A low-viscosity sealant was found to be effective in improving posterior composite wear resistance in a 5 -year clinical evaluation. After 1 year, the mean wear of the sealed restorations was about half of those not treated (4). However, hybrid composites were used in that study, which differ from nanofiller composites by presenting a greater filler size. Nanofiller composites have good wear resistance and satisfactory polishing (11), and the application of a surface sealant may not be necessary.

The aim of this in vitro study was to compare the effect of different surface-penetrating sealants on a nanofiller composite with regards to surface roughness. The null hypotheses of this study were: 1 . There is no difference on the composite surface roughness after the application of surface sealants; 2. There is no difference on the composite-sealant surface roughness after simulated toothbrushing over time.

\section{MATERIAL AND METHODS}

Forty specimens of a nanofiller composite (Filtek Z350; 3M ESPE, St. Paul, MN, USA) were obtained using a stainless steel mold $(6 \mathrm{~mm} \varnothing \times 3 \mathrm{~mm})$. The external surfaces of the mold were covered with polyester matrix strips (TDV Dental, Pomerode, SC, Brazil) that were lightly pressed with glass slabs. Polymerization was carried out with a light-emitting diode curing unit (Radi II; SDI, Victoria, Australia) at $1,000 \mathrm{~mW} / \mathrm{cm}^{2}$ for $20 \mathrm{~s}$. After $24 \mathrm{~h}$, the specimens were polished for $15 \mathrm{~s}$ with 600 -grit sandpaper under water-cooling in low-speed polishing machine, and then ultrasonically cleaned (T14; Tempo Ultrasonic Ind. Com. Ltda, Taboão da Serra, $\mathrm{SP}$, Brazil) in deionized water for $10 \mathrm{~min}$ to remove the polishing debris.

The specimens were randomly assigned to 4 groups based on the surface treatment: Control group (no treatment), Fortify (Bisco Inc., Iatasca, IL, USA), Fortify Plus (Bisco Inc.) and Biscover LV (Bisco Inc.). The surfaces of the specimens in the experimental groups were conditioned with $37 \%$ phosphoric acid (Bisco Inc.) for $20 \mathrm{~s}$, washed with air-water spray for $30 \mathrm{~s}$ and dried with an oil-free air stream. A thin coat of sealant was applied, air thinned for even distribution and light-cured according to the manufacturer's instructions.

After storage in deionized water at $37^{\circ} \mathrm{C}$ for 24 $\mathrm{h}$, surface roughness was analyzed with a profilometer (Surfcorder SE 1700; Kosakalab, Tokyo, Japan). The roughness values were expressed in micrometers $(R a)$. For each specimen, three measurements were made using a stylus tip with a $2 \mu \mathrm{m}$-diameter and 0.0001 $\mu \mathrm{m}$ accuracy. This device was adjusted to record the measurements under predefined parameters of $2.85 \mathrm{~mm}$ for the reading extension and a $0.25 \mathrm{~mm}$ cut-off.

Simulated toothbrushing was performed using toothbrush heads with soft nylon bristles (Oral B Indicator; Procter \& Gamble do Brazil, São Paulo, SP, Brazil) under a $200 \mathrm{~g}$ load (6). The toothbrush heads were changed after every 10,000 strokes. For each specimen, 30,000 strokes were performed at a frequency of 250 strokes/min. A double pass of the toothbrush head was considered a stroke. Assuming that 10,000 cycles represented approximately 1 year of toothbrushing $(7,15)$, the cycles were divided into different aging simulations of 1 week (312 strokes); 1 (1,250 strokes), 3 (2,500 strokes) and 6 months (5,000 strokes); and 1 (10,000 strokes) and 3 years (30,000 strokes). A slurry was prepared by mixing a 2:1 ratio of deionized water and a carbonate calcium particle dentifrice (Colgate Total 12; Colgate-Palmolive Ind. e Co. Ltda, São Paulo, SP, Brazil) immediately before testing. After testing, the specimens were cleaned with running water followed by an ultrasonic bath for $10 \mathrm{~min}$.

Surface roughness of each abraded specimen was determined after each simulation period and recorded as described above. Each specimen was dried with absorbent paper and roughness tracings ( $R a$ - roughness average) were taken on the test surface using Surfcorder SE 1700 (Kosakalab, Tokyo, Japan) equipment. The operating parameters were established at $\mathrm{Lt}$ (assessment length) of $2.85 \mathrm{~mm}$ and Lc (cut-off) of $0.25 \mathrm{~mm}$ (6). Three random readings were taken on each evaluated surface. Baseline R (mm) was obtained by calculating the arithmetic mean of these three readings. Comparisons before and after testing of the surface roughness of each material were determined by two-way ANOVA and Tukey's tests $(\mathrm{p}<0.05)$.

To illustrate possible events, scanning electron micrographs were taken of the surface of each resin composite before and after the abrasion procedures. Specimens were mounted on metal stubs, sputter coated with gold (SCD-050; Bal-Tec AG, Balzers, Liechtenstein) and examined under a scanning electron microscope (JSM-5600LV; JEOL Ltd., Akishima, Japan) at different magnifications. 


\section{RESULTS}

\section{Surface Roughness}

Table 1 shows the means and standard deviations of surface roughness for all the tested groups.

Without toothbrushing, Fortify Plus showed greater surface roughness than all the other materials $(p<0.05)$. From 1 week to 3 months of toothbrushing, no differences were found ( $\mathrm{p}>0.05)$. From 6 months to 1 year, Fortify Plus showed greater surface roughness when compared with the other groups $(\mathrm{p}<0.05)$. At the 3 -year evaluation, no differences were found ( $p>0.05$ ).

At each tested time, Fortify Plus presented a greater surface roughness that at the initial time $(p<0.05)$. Among the other groups, no significant differences were found over time ( $p>0.05)$.

\section{SEM Analysis}

The SEM micrographs confirmed the results. Figures 1A-1C present the sealant-free surface of Z-350 at the initial control time, after 1 week and after 3 months of toothbrushing simulation, respectively.

Before toothbrushing simulation, Fortify (Fig. 1D), Fortify Plus (Fig. 1G) and Biscover LV (Fig. 1J) were observed on the composite surface. Fortify Plus showed a thicker layer than Fortify and Biscover LV, which were similar to each other.

After 1 week of toothbrushing simulation, the wear of Fortify (Fig. 1E) and Biscover LV (Fig. 1K) were not uniform, as highlighted by arrows. The black arrows indicate the sealant while the white arrows indicate the exposed resin matrix (Fig. 1E and $1 \mathrm{~K}$ ).

Table 1. Means $(\mu \mathrm{m})$ and standard deviations of surface roughness.

\begin{tabular}{lcccc}
\hline Time & Control & Fortify & Fortify Plus & Biscover LV \\
\hline Initial & $0.11(0.02) \mathrm{Aa}$ & $0.08(0.01) \mathrm{Aa}$ & $0.21(0.10) \mathrm{Ab}$ & $0.08(0.05) \mathrm{Aa}$ \\
1 week & $0.11(0.01) \mathrm{Aa}$ & $0.09(0.01) \mathrm{ABa}$ & $0.14(0.04) \mathrm{Aa}$ & $0.14(0.07) \mathrm{Aa}$ \\
1 month & $0.13(0.02) \mathrm{Aa}$ & $0.11(0.01) \mathrm{BCa}$ & $0.21(0.15) \mathrm{Aa}$ & $0.14(0.07) \mathrm{Aa}$ \\
3 months & $0.13(0.02) \mathrm{Aa}$ & $0.12(0.02) \mathrm{Ca}$ & $0.20(0.10) \mathrm{Aa}$ & $0.19(0.10) \mathrm{Aa}$ \\
6 months & $0.14(0.06) \mathrm{Aab}$ & $0.11(0.02) \mathrm{BCa}$ & $0.23(0.11) \mathrm{Bb}$ & $0.17(0.10) \mathrm{Aab}$ \\
1 year & $0.12(0.03) \mathrm{Aa}$ & $0.12(0.02) \mathrm{Ca}$ & $0.22(0.12) \mathrm{Bb}$ & $0.19(0.07) \mathrm{Aab}$ \\
3 years & $0.18(0.07) \mathrm{Aa}$ & $0.15(0.04) \mathrm{Ca}$ & $0.23(0.10) \mathrm{Ba}$ & $0.24(0.12) \mathrm{Aa}$ \\
\hline
\end{tabular}

Different uppercase letters in the same column and lowercase letters in the same row indicate statistically significant difference $(\mathrm{p}<0.05)$.
After 3 months of toothbrushing, Fortify (Fig. 1F) and Fortify Plus (Fig. 1I) still remained on the composite resin surface. Biscover LV (Fig. 1L) was almost totally removed and the composite filler particles exposed, similar to the control (Fig. 1C).

Surface sealant removal did not occur uniformly when considering the total observed area, as shown in Figure 2.

\section{DISCUSSION}

When surface-penetrating sealants were launched on the market, a variety of laboratory studies and clinical trials evaluated these materials under different protocols $(4-6,12,13)$. These studies seem to reveal a consensus about the effectiveness of sealants on reducing microleakage, despite the inability to totally avoid this occurrence (12).

Despite the progress of bonding systems, adhesion is still based on mechanical interlocking of dentin bonding systems to demineralized dentin. Dentin bonding systems, combined with resin-based restorative materials, undergo polymerization shrinkage $(15,16)$, which may create gaps at the interface. This is the rationale of surface-penetrating sealants, which can penetrate these gaps and minimize the occurrence of microleakage. Previous studies have shown that this effect is relevant mainly along the dentin margins (17) by improving the marginal adaptation of composite restorations (18).

Surface-penetrating sealants also reduced the wear of composite resins and minimized the surface roughness under in vitro conditions and in clinical evaluations (4-6). A low-viscosity resin applied on the surface of a polymerized composite resin restoration could penetrate into the structural microgaps and microfractures, promoting marginal sealing (19). This material is a nanocomposite that contains only nanomeric particles and nanoclusters as inorganic fillers. Recently, a new composite resin based on nanotechnology was developed (20) promoting an improved chemical integration of the filler particles, which contains only nanomeric particles and nanoclusters (21) within the composite matrix (10), 
while reducing the wear rates of these composites (22). However, few studies have evaluated the relationship between this nanofiller composite resin and the surface sealant $(14,23)$. Due to this lack of information in the literature, this study evaluated the behavior of this resin with surface sealants with and without filler.

According to the obtained results, the application of different surface-penetrating sealants apparently did not improve the surface roughness of nanofiller materials after 30,000 strokes of toothbrushing simulation. Thus, the null hypotheses of the present study were rejected.

When the control group was compared with specimens protected with Fortify, no differences were detected at any evaluated time. It is possible to speculate that, despite the wettability and low viscosity of this sealant, it did not promote better protection to the organic matrix of the nanofiller composite resin (20).

When filler was added to the sealant, as with Fortify Plus, its performance worsened when compared with the control group after 6 months of toothbrushing. The wear of the organic matrix of this sealant potentially allowed the filler to be protruded or lost, resulting in a rougher surface. The surface sealants have limited capacity to penetrate into structural defects as small as 1 or $2 \mu \mathrm{m}$ (24); therefore, the sealant did not perform as expected on nanofiller surfaces.

Finally, the use of Biscover LV was also ineffective, corroborating with Perez et al. (23), who

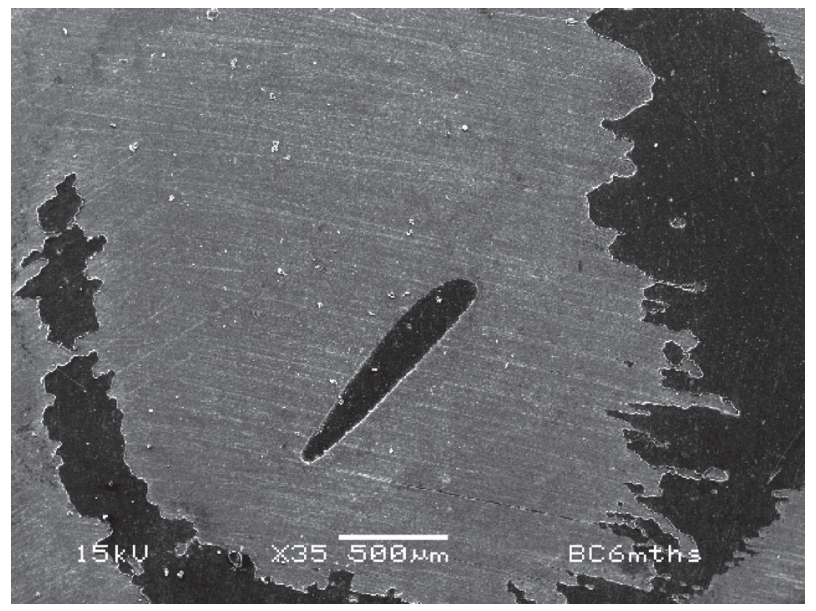

Figure 2. SEM micrograph of Biscover LV after 6 months of toothbrushing.
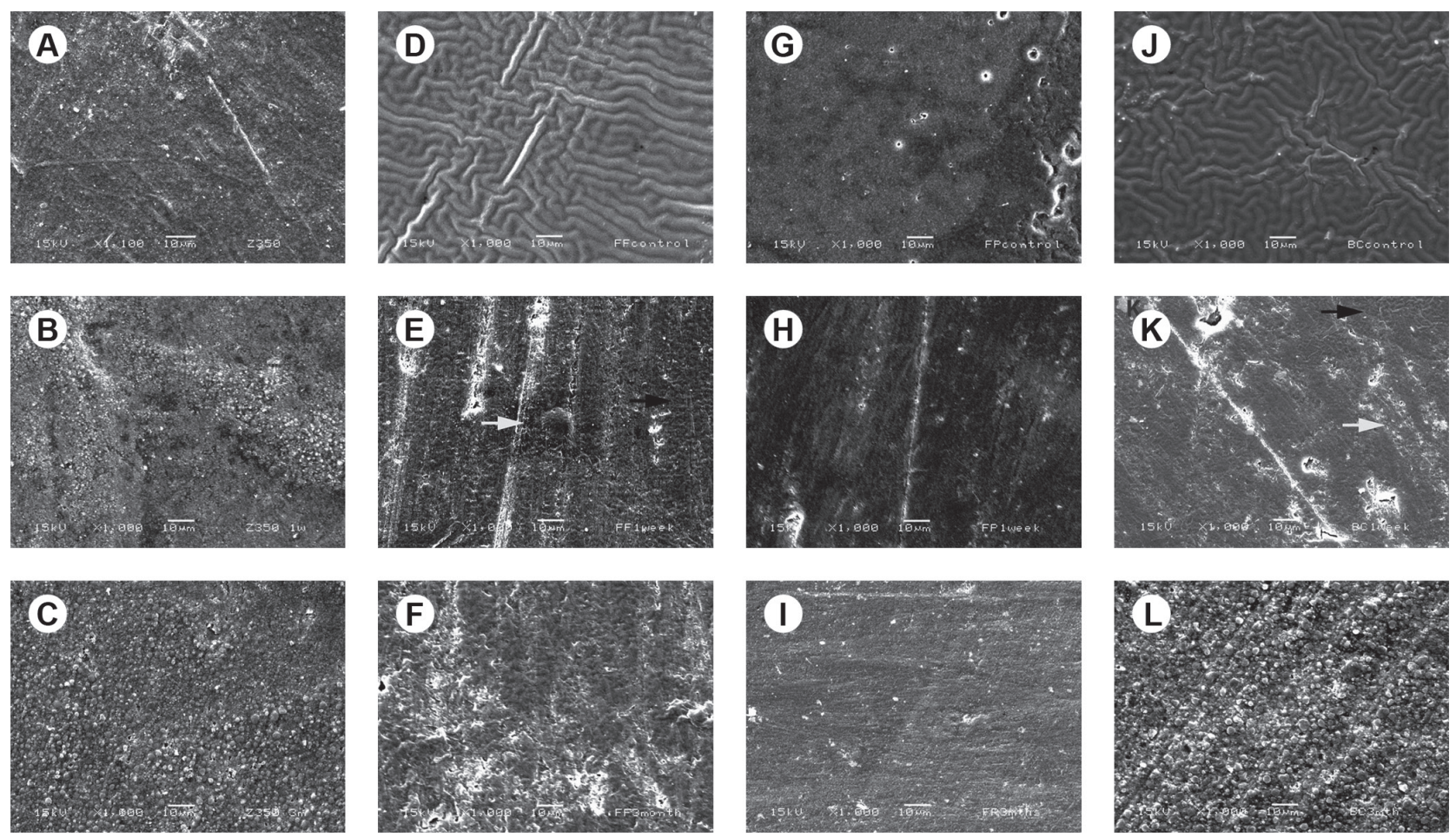

Figure 1. Composite figure of SEM micrographs of the control group at the initial control time (A), after 1 week (B) and 3 months (C) of toothbrushing simulation, and Fortify, Fortify Plus and Biscover LV at the initial time (D, E, F), after 1 week (G, H, I) and 3 months of toothbrushing simulation $(\mathrm{J}, \mathrm{K}, \mathrm{L})$. Black arrows indicate the sealant and white arrows indicate the exposed resin matrix. 
proposed its use alone to provide an initial and temporary gloss and polish (13).

Microscopically, a wave texture on Figures 1D (Fortify) and $1 \mathrm{~J}$ (Biscover LV) can be observed, probably due to evaporation of the solvent from the material prior to polymerization. Cilli et al. (14) also reported these findings on Biscover surface. However, this is not observed in Figure $1 \mathrm{G}$ (Fortify Plus) due to the presence of the sealant filler.

Although surface-penetrating sealants have been claimed to minimize some limitations of resin-based materials, they seem to be ineffective in protecting a nanofiller resin surface against toothbrushing procedures. The surface-penetrating sealant was useless for the nanofiller composite resins as the filler removal from the surface during toothbrushing resulted in very small voids, which did not interfere with the surface roughness (25).

One limitation of this study was the quantification of sealant remaining on the composite surface and evaluation of the bond strength between the sealant and resin. As seen in Figure 2, the sealant appeared to be removed in blocks, not gradually as expected. Other studies, such as microleakage evaluations, should be conducted associated with nanofiller restorations, since microleakage still represents the greatest challenge to resin-based materials, even in the nanotechnology era. Few studies in the literature deal with the surface quality of nanoparticle composites using sealants with and without filler.

In conclusion, the tested surface-penetrating sealants do not seem able to improve the surface roughness performance of a nanofiller composite resin, highlighting the potential of the nanofil technology in obtaining an adequate surface roughness without the use of any sealant.

\section{RESUMO}

Este estudo avaliou a efetividade de diferentes selantes aplicados a uma resina nanoparticulada. Quarenta espécimes de Filtek Z-350 foram obtidos depois da inserção do material em um molde de aço inoxidável seguido por fotoativação por $20 \mathrm{~s}$. Os grupos foram divididos $(n=10)$ de acordo com o tratamento superficial aplicado: Grupo controle (sem tratamento superficial), Fortify, Fortify Plus ou Biscover LV. Os espécimes foram submetidos a escovação simulada usando uma carga de $200 \mathrm{~g}$ e 250 ciclos $/ \mathrm{min}$ para simular 1 semana, 1,3 e 6 meses e 1 e 3 anos, considerando que 10.000 ciclos equivalem a um ano de escovação. Escovas Oral-B de cabeça macia e dentifrício Colgate Total diluído a 1:2 em água foram utilizados. Depois de cada período de simulação, a rugosidade superficial foi medida em triplicata. Os dados foram submetidos à ANOVA de dois fatores e ao teste de Tukey com nível de $95 \%$ de confiança. Os espécimes foram observados em microscopia eletrônica de varredura (MEV) depois de cada ciclo de escovação. O grupo controle não foi diferente $(p>0,05)$ que os outros grupos, exceto pelo Fortify Plus $(p<0,05)$, que foi mais rugoso. Nenhuma diferença $(p>0,05)$ foi observada em 1 mês de simulação entre os grupos experimentais e o controle. Fortify e Fortify Plus apresentaram rugosidade regular com o tempo, diferindo da inicial em todos os tempos. Nenhum dos grupos selados mostrou melhor desempenho $(\mathrm{p}>0,05)$ que o grupo controle em qualquer um dos tempos. MEV ressaltou as diferenças encontradas durante o teste de rugosidade. Selantes de penetração de superfície não melhoram a rugosidade da resina nanoparticulada.

\section{REFERENCES}

1. Coelho-de-Souza FH, Rocha Ada C, Rubini A, Klein-Junior CA, Demarco FF. Influence of adhesive system and bevel preparation on fracture strength of teeth restored with composite resin. Braz Dent J 2010;21:327-331.

2. Dall'Magro E, Correr AB, Costa AR, Correr GM, Consani RL, Correr-Sobrinho L, et al.. Effect of different photoactivation techniques on the bond strength of a dental composite. Braz Dent J 2010;21:220-224.

3. de Paula AB, Tango RN, Sinhoreti MA, Alves MC, PuppinRontani RM. Effect of thickness of indirect restoration and distance from the light-curing unit tip on the hardness of a dualcured resin cement. Braz Dent J 2010;21:117-122.

4. Dickinson GL, Leinfelder KF. Assessing the long-term effect of a surface penetrating sealant. J Am Dent Assoc 1993;124:68-72.

5. dos Santos PH, Consani S, Correr Sobrinho L, Coelho Sinhoreti MA. Effect of surface penetrating sealant on roughness of posterior composite resins. Am J Dent 2003;16:197-201.

6. dos Santos PH, Pavan S, Consani S, Sobrinho LC, Sinhoreti $\mathrm{MA}$, Filho JN. In vitro evaluation of surface roughness of 4 resin composites after the toothbrushing process and methods to recover superficial smoothness. Quintessence Int 2007;38:e247-e253.

7. Wang L, Garcia FC, Amarante de Araujo P, Franco EB, Mondelli RF. Wear resistance of packable resin composites after simulated toothbrushing test. J Esthet Restor Dent 2004;16:303-314; discussion 14-15.

8. Azevedo CGS, De Goes MF, Ambrosano GMB, Chan DCN. 1-year clinical study of indirect resin composite restorations luted with a self-adhesive resin cement: effect of enamel etching. Braz Dent J 2012;23:97-103.

9. Valentini F, Oliveira SG, Guimarães GZ, Barbosa RP, Moraes RR. Effect of surface sealant on the color stability of composite resin restorations. Braz Dent J 2011;22:365-368.

10. Delfino CS, Duarte S, Jr. Effect of the composite surface sealant application moment on marginal sealing of compactable composite resin restoration. J Mater Sci Mater Med 2007;18:2257-2261.

11. Mitra SB, Wu D, Holmes BN. An application of nanotechnology in advanced dental materials. J Am Dent Assoc 2003;134:1382-1390.

12. Owens BM, Johnson WW. Effect of new generation surface sealants on the marginal permeability of Class $\mathrm{V}$ resin composite restorations. Oper Dent 2006;31:481-488.

13. Lowe RA. Using BisCover surface sealant/polish on direct and indirect composite and bisacrylic provisional restorations. Compend Contin Educ Dent 2004;25:400-401.

14. Cilli R, de Mattos MC, Honorio HM, Rios D, de Araujo PA, Prakki A. The role of surface sealants in the roughness of composites after 
a simulated toothbrushing test. J Dent 2009;37:970-977.

15. Guiraldo RD, Consani S, Consani RL, Berger SB, Mendes WB, Sinhoreti MA, et al.. Comparison of silorane and methacrylatebased composite resins on the curing light transmission. Braz Dent J 2010;21:538-542.

15. Shabayek NM, Hassan FM, Mobarak EH. Effect of using siloranebased resin compostie for restoring conservative cavities on the changes in cuspal deflection. Oper Dent 2012. [Epub ahead of print. DOI: http://dx.doi.org/10.2341/12-035-L].

17. Suzuki T, Kyoizumi H, Finger WJ, Kanehira M, Endo T, Utterodt A, et al.. Resistance of nanofill and nanohybrid resin composites to toothbrush abrasion with calcium carbonate slurry. Dent Mater J 2009;28:708-716.

18. Moncada G, Fernández E, Martín J, Arancibia C, Mjör IA Gordan VV. Increasing the longevity of restorations by minimal intervention: a two-year clinical trial. Oper Dent 2008;33:258-264.

19. Judes H, Lieberman R, Serebro L, Bem Amar A. Rebonding as a method of controlling marginal microleakage in composite resin restorations. N Y J Dent 1992;52:137-143.

20. Davis N. A nanotechnology composite. Compend Contin Educ
Dent 2003;24:662,665-667,669-670

21. Castañeda ER, Silva LA, Gaton-Hernández P, Consolaro A, Rodriguez EG, Silva RA, et al.. FIltek silorane and Filtek supreme $\mathrm{XT}$ resins: tissue reaction after subcutaneous implantation in isogenic mice. Braz Dent J 2011;22:105-110.

22. Yap AU, Tan CH, Chung SM. Wear behavior of new composite restoratives. Oper Dent 2004;29:269-274.

23. Perez CR, Hirata RJ, da Silva AH, Sampaio EM, de Miranda MS. Effect of a glaze/composite sealant on the 3-D surface roughness of esthetic restorative materials. Oper Dent 2009;34:674-680.

24. Shinkai K, Suzuki S, Leinfelder KF, Katoh Y. Effect of surface-penetrating sealant on wear resistance of luting agents. Quintessence Int 1994;25:767-771.

25. Koh R, Neiva G, Dennison J, Yaman P. Finishing systems on the final surface roughness of composites. J Contemp Dent Pract 2008;9:138-145.

Received September 25, 2011

Accepted November 30, 2012 